\title{
Perception of Seriousness and preventive health actions of Patients WITH TYPE 2 DIABETES
}

\section{Authors:}

Susanna C.D. Wright ${ }^{1}$ Jacoba J.M. Jansen van

Rensburg

Johanna E. Maree

\section{Affiliations:}

${ }^{1}$ School of Nursing

Science, Tshwane

University of Technology,

South Africa

\section{Correspondence to:}

Susanna C.D. Wright

\section{e-mail:}

wrightscd@tut.ac.za

\section{Postal address:}

Adelaide Tambo School of Nursing Science, Private Bag x 680, Pretoria, 0001, South Africa

\section{Keywords:}

type 2 diabetes;

perceptions; seriousness; change of lifestyle; Health Promotion Model

\section{Dates:}

Received: 14 Jan. 2008

Accepted: 13 May 2009

Published: 21 Aug. 2009

How to cite this article: Wright, S.C.D., Jansen van Rensburg, J.J.M

\& Maree, J.E., 2009, 'Perception of seriousness and preventive health actions of patients with type 2 diabetes', Health $S A$ Gesondheid 14(1), Art. \#462, 8 pages. DOI: $10.4102 /$ hsag.v14i1.462

\section{This article is available} at:

http://www.hsag.co.za

\section{(c) 2009. The Authors.} Licensee: OpenJournals Publishing. This work is licensed under the Creative Commons Attribution License.

\section{ABSTRACT}

Diabetes mellitus is one of the most common chronic health conditions in the world. Though type 2 diabetes is a very serious condition, it is the complications that go with it that cause major morbidity and mortality. It is possible for a person with type 2 diabetes to lead a normal, happy life with the adequate treatment and motivation. The treatment involves increased physical activity, reducing weight if overweight, following a healthy diet and oral drugs or insulin injections. Patients deliver $95 \%$ of their care. According to the Health Promotion Model a nurse can support patients by focussing on the benefits of the treatment, teaching them to overcome management barriers and by giving positive feedback. The purpose of this study was to determine whether type 2 diabetes patients who were educated and counselled at a Centre for Diabetes in Limpopo Province, South Africa, perceive their condition as serious and change their lifestyle to prevent complications. The design was an exploratory, contextual, quantitative survey. A convenient sample $(n=40)$ was chosen from patients attending the Centre for Diabetes. The data method was self-report using a pre-testing questionnaire and descriptive statistics to analyse the data. The results of the study indicate that though the majority of the groups' physical measurements were above normal (obesity $85 \%$, hypertension $35 \%, \mathrm{HbA} 1 \mathrm{c} 65 \%$ and waist circumference $70 \%$ ), they perceived the diabetes diagnosis as not serious $(87.5 \%)$ and well controlled (87.5\%). Solutions for educating individuals to change their lifestyles to prevent complications when they are feeling well have not yet been found.

\section{OPSOMMING}

Diabetes mellitus is ' $n$ algemene chroniese gesondheidstoestand. Alhoewel tipe 2-diabetes 'n ernstige toestand is, veroorsaak komplikasies die meeste morbiditeit en mortaliteit. Dit is moontlik vir ' $n$ persoon met tipe 2-diabetes om 'n normale, gelukkige lewe te lei met die nodige behandeling en motivering. Behandeling behels verhoogde fisiese aktiwiteit, gewigsverlies, 'n gesonde dieet en orale medikasie of insulienbehandeling. Pasiënte is egter verantwoordelik vir $95 \%$ van hul behandeling. Volgens die Gesondheidsbevorderingsmodel kan 'n verpleegkundige 'n pasiënt ondersteun deur te fokus op die voordele van behandeling, voorligting om probleme te oorkom en deur positiewe terugvoering. Die doel van die studie was om te bepaal of die pasiënte met tipe 2-diabetes wat voorligting en berading by ' $n$ Sentrum vir Diabetes in Limpopo Provinsie ontvang, hul toestand as ernstig beskou en of hulle hul lewenswyse verander ten einde komplikasies te voorkom. Die ontwerp was 'n ondersoekende kwantitatiewe opname. Die gerieflikheidsteekproef was veertig deelnemers $(n=40)$. Die data-insamelingsmetode was self-rapportering deur middel van ' $n$ vraelys en die data is met behulp van beskrywende en statistiese analise ontleed. Die resultate dui daarop dat die meerderheid van die groep se fisiese lesings hoër as normaal was (oorgewig 85\%, hipertensie $35 \%$, $\mathrm{HbA1c} 65 \%$ en middellyn $70 \%$ ). Die meeste van die deelnemers $(87.5 \%)$ het hul diagnose van tipe 2 diabetes as nie ernstig nie en goed gekontroleerd beskou. Die oplossing oor hoe om mense te leer om hul lewenswyse te verander om komplikasies te voorkom terwyl hulle op die oomblik nog goed voel, is nog nie bepaal nie.

\section{INTRODUCTION}

Diabetes mellitus is one of the most common chronic health conditions worldwide. The number of people with diabetes is growing globally, especially type 2 diabetes (Clark 2004:ix). According to Distiller (2006:7), a global epidemic of type 2 diabetes is underway. The expected global incidence in 2010 will be more than 200 million, and in 2020 more than 300 million people will have the condition.

Type 2 diabetes or maturity onset diabetes is a condition which is caused by progressive failure of the $\beta$-cells in the pancreas to produce enough insulin for glucose metabolism, as well as/or resistance of the body to insulin. Failure of the $\beta$-cells or primary insulinopaenia is typically seen in African and Afro-American people. Primary insulin resistance is characterised by metabolic syndrome, which consists of five components: hyper-insulinaemia, glucose intolerance, hypertension, elevated triglycerides and decreased high density lipoprotein-cholesterol (Distiller 2006:8). Caballero (2007) emphasises that the pathological process is continuous, progressive and irreversible.

Though type 2 diabetes is a very serious condition, it is its complications that cause major morbidity and mortality. The short-term complications of type 2 diabetes are hypo- or hyperglycaemia and ketoacidosis. Long-term complications are cardiac disease, hypertension, and damage to kidneys, eyes and peripheral neuropathy (Clark 2004:11). Caballero (2007) adds that diabetes is the leading cause of non-traumatic amputations. To emphasise the seriousness of the complications of diabetes mellitus, Casellini and Vinik (2007:550) write that the major morbidity is foot ulceration which can lead to gangrene and limb loss. Indeed, globally, an amputation is performed every 30 seconds. These complications can be prevented by proper blood glucose control and lifestyle changes, for example cessation of smoking, regular exercise and meal planning.

It is possible for a person with type 2 diabetes to lead a normal, happy life with the adequate treatment and motivation. The treatment involves increased physical activity, reducing weight if overweight, 
following a healthy diet and oral drugs or insulin injections. To manage the condition, a team approach is needed where the patient is the captain of the team and the doctors, diabetes educator, ophthalmologist, dietician, podiatrist and biokineticist are team players, all with the same goal - to control blood glucose levels and prevent complications. Education and counselling play a central role in the management of a chronic disease such as diabetes mellitus (Visser \& Snoek 2004:252).

Diabetes is unique among chronic illnesses in the degree to which the patient's behaviour influences both the application and outcomes of therapy. The patient performs $95 \%$ of the care he or she requires by themselves. However, patients often only realise the seriousness of the condition when they develop complications (Clark 2004:ix). Tan, in a study among Chinese individuals with type 2 diabetes in Malaysia, found that few participants practiced complication preventative measures because of a lack of perceived seriousness of diabetes and a lack of perceived susceptibility to diabetic complications (Tan 2004). Huang et al. (2007:2478) also investigated patients' perceptions of diabetes-related complications and found that the greatest perceived burden on quality of life is end-stage complications. They also found that comprehensive diabetes treatments are viewed very negatively.

The importance of the patient's role in his/her treatment regimen is underscored in a report by Visser and Snoek (2004:251). The authors report that obesity is a two-fold problem affecting both physical health and psychological well-being. Weight loss is considered as one of the major obstacles in the management of diabetes as, with the exception of surgical treatments, all obesity treatment approaches, for example behavioural, dietetic or pharmacological intervention failed to achieve significant and long-lasting weight loss.

\section{RESEARCH PROBLEM AND PURPOSE OF THE STUDY}

Type 2 diabetes is a condition which can result in very serious complications if the level of blood glucose is not controlled well. Health care providers operate as a team to assist patients to control their blood glucose levels, in order to prevent complications. Patients are expected to monitor their blood glucose levels frequently, increase their physical activity, follow a healthy diet and take their medication as prescribed. As family members have an important influence on the patient's commitment to make lifestyle adjustments, it is important to involve them in the treatment plan where possible. However, if patients do not perceive their condition as serious or perceive a threat to their longevity, the education and counselling may not result in positive health behaviour.

According to the Health Promotion Model (Pender, Murdaugh \& Parsons 2002:36), a nurse can support a patient by focussing on the benefits of the treatment, teaching him or her to overcome management barriers and by giving positive feedback. Such education and training is a major component of the management of patients using a Centre for Diabetes in Limpopo Province. The focus is health promotion whilst being a diabetic as well as gaining the necessary knowledge and skills to manage their condition at home. The aim of the study was to discover whether education and counselling changed the patients' perceptions regarding the seriousness of their condition and the need for lifestyle changes.

\section{Research problem}

The research problem for this study was therefore that it was not known whether patients diagnosed with type 2 diabetes and managed at a Centre for Diabetes in Limpopo Province for at least six months perceived their condition as serious and changed their lifestyle to prevent complications.

\section{Research purpose}

The purpose of the study was to determine whether patients educated and counselled at a Centre for Diabetes in Limpopo Province perceive their condition as serious and consequently change their lifestyle to prevent complications. Without understanding the patients' knowledge and perceptions relating to their condition, the health care practitioners would not know whether their education and counselling efforts changed the perceptions of the patients regarding the seriousness of their condition and whether they changed their lifestyle in line with a health-promoting lifestyle.

\section{THEORETICAL FOUNDATION OF THE STUDY}

The theoretical basis of this study is the Health Belief Model of Pender et al. (2002:36). The model postulates that health-seeking behaviour is influenced by a person's perception of a threat posed by a health problem, and the value associated with actions aimed at reducing the threat. If the person does not perceive the health threat to be serious, the possibility of committing to health-promoting behaviour is very low. The major components of the model are described as a background to the study.

\section{Individual perceptions}

Individual perceptions include people's perceptions of how susceptible they would be to a disease or condition, and how serious that disease or condition could be to their continued wellbeing. Their willingness to change their behaviour depends on their evaluation of how possible such a change would be or which barriers they would encounter. Pender et al. (2002:37) state that beliefs about personal susceptibility and the seriousness of a specific illness are combined to produce the degree of threat or negative valence of that illness. Perceived susceptibility reflects people's feelings of personal vulnerability to a specific health problem. Perceived seriousness or severity of a given health problem can be combined either by the degree of emotional arousal created by the thought of having the disease or by the medical and clinical or social difficulties that individuals believe a given health condition would create for them. Perceived barriers are perceptions concerning the potential negative aspects of taking action such as danger, unpleasantness, inconvenience and time required.

\section{Modifying factors}

A person's behaviour may be influenced by specific modifying factors, which include demographic and socio-psychological factors and structural variables. Demographic factors include aspects such as age, gender, race or socio-cultural group, while socio-psychological factors consist of a person's personality, social class, peer- and reference-group pressure. Structural variables, knowledge about, or prior contact with the disease, as well as cues to action, affect tendencies only indirectly through their relationship with the perception of the threat.

\section{Likelihood of action}

The likelihood that a person may change a specific behaviour of action depends on the perceived benefits of preventive action minus the perceived barriers to preventive action and the likelihood of taking recommended preventive health action.

At the Centre for Diabetes, the health care providers realise that patients need continuous support to manage type 2 diabetes and they are committed to providing support. They encourage the patients by being role models of a healthy lifestyle and by giving health education continuously. Patients are observed frequently to determine whether they monitor their blood glucose levels regularly and use their medication as prescribed. Family members are involved by means of including them in health education, especially with regards to diet. 


\section{Central theoretical statement}

If patients diagnosed with type 2 diabetes perceive their condition as serious, they will be more likely to commit to and maintain recommended health action.

\section{RESEARCH METHODS AND DESIGN}

The research methods and design for this study were as follows:

\section{Research context}

The research study was of a contextual nature. The context is the environment where the study tooh place and where the results were guaranteed. Patients from all over Limpopo Province are referred to a Centre for Diabetes in Limpopo. At the Centre, there are two doctors and a registered nurse who are specialists in diabetes care, a dietician who visits the Centre twice a week, a podiatrist who visits once a week and an ophthalmologist to whom patients can be referred.

The patients were from different cultural backgrounds, namely Sotho, Venda, Tsonga, Afrikaans and English. Most of the patients were employed and in the middle to higher income groups. Patients who were not members of a medical aid company were in the position to pay cash for their treatment. An average of 115 type 2 diabetes patients are seen for follow-up per month, with approximately 15 new patients per month.

\section{Research design}

The design took the form of a quantitative survey (Denscombe 2007:10). The quantitative component focused on gathering data about health-promoting behaviour from the patients, and the perceptions of the respondents regarding the seriousness of their condition were measured using visual analogue scales.

\section{Population}

According to Polit and Hungler (1997:43), the population used in research can be defined as the aggregate or totality of all the objects, subjects or members that conform to a set of specifications. The target population for this study was type 2 diabetes patients from Limpopo Province treated at a Centre for Diabetes.

Convenience sampling was used, which, according to Brink (2001:140), is accidental or availability sampling and involves choosing readily available people for the study. The criteria for selection of participants for the study stipulated that patients were:

- diagnosed with type 2 diabetes

- managed for type 2 diabetes for at least six months at the Centre for Diabetes in Limpopo Province

- visiting the Centre during the month chosen for data gathering

- willing to participate.

The sample size for the study was 40 participants. The decision in terms of the sample size was governed by the average number of patients who consulted the Centre during a one-month period and who complied with the inclusion criteria.

\section{Data gathering}

The data gathering method for the study was self-report. Questions can be used to explore the participants' perceptions, attitudes, beliefs, feelings, motives, plans, past events, knowledge levels and to gather factual information about the participants (Brink 2001:153). The data gathering instrument was a questionnaire. The questionnaire was based on healthpromoting behaviour as explained to patients during patient educational sessions as well as on the basic tenets of the Health Belief Model (Pender et al. 2002:36). The questionnaire consisted of five sections. The content of the sections was as follows:

- Section A focused on demographic information, which included the independent variables age, marital status, gender, education, employment and socio-cultural group

- In Section B information was gathered regarding the participant's type 2 diabetes diagnosis and medication, as well as the participant's evaluation of how well the type 2 diabetes was controlled at that moment

- In Section C data was collected in terms of the health education received relating to type 2 diabetes

- In Section D the participants' risk perception and lifestyle modification to control their type 2 diabetes was investigated

- Section E focused on physical measures, which were weight, height, blood pressure, $\mathrm{HbA1c}$ and waist circumference.

Due to the quantitative nature of the study, visual analogue scales were used to measure the perceptions of the respondents regarding the seriousness of their condition, the importance of changing their lifestyle, as well as the importance of consulting eye and foot specialists regularly. The range of the visual analogue scales was from $0-10$.

The questionnaire was evaluated for face validity by an expert in diabetes care, a medical practitioner specialising in diabetes care, and was pre-tested prior to data gathering to ensure that the data gathered would answer the research question. The participants in the pre-test complied with the same inclusion criteria but did not form part of the final group. No changes were made to the questionnaire after the pre-test.

Written permission to conduct the study was obtained from the management at the Centre for Diabetes as well as from the participants. A private room was used for completing the questionnaire and a marked box was placed in the room for the completed questionnaires. The questionnaires were numbered sequentially to ensure anonymity and confidentiality. The questionnaires were in English. Venda or Tsonga patients who could not speak English were usually accompanied by family members who could speak English.

\section{Data analysis}

Descriptive statistics were used to describe and summarise the data. For the analysis of the visual analogue scales, responses from $0-3$ were considered as a negative response and responses between 7 and 10 were seen as positive responses. The data are presented as frequency measures for example proportions and percentages. As the variables were measured on a nominal or ordinal scale, the Chi-square test was used to determine if the frequency in each category is different from what would be expected by chance (Lo Biondo-Wood \& Haber 2006:374-375). Using the Chi-square is appropriate, as the test is distributionfree and appropriate for convenient samples. The SPSS version 15 statistical analysis programme was used to analyse the data.

\section{Validity and reliability}

The validity and reliability of the data gathering instrument for the quantitative component of the study was ensured by means of the following:

- The data collection instrument was appropriate for the type of patients seen at the Centre, in terms of their age, reading level, health status, culture and language (Brink 2001:173)

- The instrument was efficient, as it required minimum effort and measured the extent to which the participants changed their lifestyle

- The questionnaire was assessed by a medical practitioner specialising in type 2 diabetes for layout, clarity and completeness, and was pre-tested prior to actual use

- The participants completed the questionnaire during their routine appointment whilst waiting for the consultation. 
TABLE 1

Participants' physical measurement risk factors $(n=40)$

\begin{tabular}{lll}
\hline & N & $\%$ \\
\hline BMI CATEGORY & & \\
Normal: & 6 & 15 \\
Overweight: BMI $\geq 25-29.9 \mathrm{~kg} / \mathrm{m}^{2 a}$ & 26 & 65 \\
Obese: BMI $\geq 30-34.9 \mathrm{~kg} / \mathrm{m}^{2}$ & 8 & 20 \\
BLOOD PRESSURE & & \\
Normal: & 26 & 65 \\
Hypertensive: $>140 / 90 \mathrm{mmHg}{ }^{b}$ & 14 & 35 \\
HbA1C & & \\
Normal: & 14 & 35 \\
High: $>>$ 7\% & 26 & 65 \\
WAIST CIRCUMFERENCE & & \\
Normal: & 12 & 30 \\
High: $>$ d $102 \mathrm{~cm}$ (men) and > 88 cm (women) & 28 & 70 \\
\hline
\end{tabular}

TABLE 2

Perception of control of type 2 diabetes and comparison with dependent variables and physical measurements

\begin{tabular}{|c|c|c|c|c|}
\hline QUESTION & $\begin{array}{r}\text { GOOD } \\
\text { CONTROL }\end{array}$ & $\begin{array}{r}\text { POOR } \\
\text { CONTROL }\end{array}$ & $x^{2}$ & $\mathrm{p}$ \\
\hline & $\%$ & $\%$ & & \\
\hline \multicolumn{5}{|l|}{$\begin{array}{l}\text { When you heard your diagnosis } \\
\text { of type } 2 \text { diabetes, did you think } \\
\text { you were seriously ill? }\end{array}$} \\
\hline Yes $(n=23)$ & 57.1 & 42.9 & 22.5 & 0.34 \\
\hline No $(n=17)$ & 60.0 & 40.0 & & \\
\hline \multicolumn{5}{|l|}{$\begin{array}{l}\text { On a scale of } 0-10 \text {, how serious } \\
\text { do you think your type } 2 \\
\text { diabetes is now? }\end{array}$} \\
\hline Not at all $(n=16)$ & 93.3 & 6.3 & 22.5 & 0.03 \\
\hline Moderately $(n=17)$ & 82.4 & 17.6 & & \\
\hline Very $(n=5)$ & 80.0 & 20.0 & & \\
\hline \multicolumn{5}{|l|}{$\begin{array}{l}\text { Importance of changing lifestyle } \\
\text { categories }\end{array}$} \\
\hline Not at all $(n=1)$ & 100.0 & 0.0 & 44.8 & 0.00 \\
\hline Moderately $(n=5)$ & 60.0 & 40.0 & & \\
\hline Very $(n=32)$ & 90.6 & 9.4 & & \\
\hline \multicolumn{5}{|l|}{$\begin{array}{l}\text { Importance of consulting a foot } \\
\text { specialist }\end{array}$} \\
\hline Moderately $(n=10)$ & 100.0 & 0.0 & 9.2 & 0.002 \\
\hline \multicolumn{5}{|l|}{$\begin{array}{l}\text { Importance of consulting a } \\
\text { dietician }\end{array}$} \\
\hline Not at all $(n=1)$ & 0.0 & 100.0 & 22.5 & 0.00 \\
\hline Moderately $(n=9)$ & 88.9 & 11.1 & & \\
\hline Very $(n=23)$ & 91.3 & 8.7 & & \\
\hline \multicolumn{5}{|l|}{ BMI categories } \\
\hline Normal $(n=6)$ & 100.0 & 0.0 & 18.2 & 0.00 \\
\hline Overweight $(n=28)$ & 88.5 & 11.5 & & \\
\hline Obese $(n=8)$ & 75.0 & 25.0 & & \\
\hline \multicolumn{5}{|l|}{ Blood pressure } \\
\hline Normal $(n=26)$ & 92.3 & 7.7 & 3.6 & 0.05 \\
\hline $\operatorname{High}(n=14)$ & 78.6 & 21.4 & & \\
\hline \multicolumn{5}{|l|}{$\mathrm{HbA1c}$} \\
\hline Normal $(n=13)$ & 100.0 & 0.0 & 4.3 & 0.03 \\
\hline High $(n=26)$ & 80.8 & 19.2 & & \\
\hline \multicolumn{5}{|l|}{ Waist circumference } \\
\hline Normal $(n=11)$ & 100.0 & 0.0 & 7.4 & 0.006 \\
\hline High $(n=28)$ & 82.1 & 17.9 & & \\
\hline
\end{tabular}

\section{ETHICAL CONSIDERATIONS}

The following ethical principles were followed in the study:

- Informed consent. Written informed consent was obtained from the participants. Permission was obtained from the management of the Centre for Diabetes to conduct the research.

- Ethics approval. The research proposal was approved by the Ethics Committee of Tshwane University of Technology (\#2005/10/003).

- Nonmaleficence. Participants were not harmed in any way. Privacy was ensured and anonymity and confidentiality maintained. Participants were selected for reasons directly related to the problem being studied.

\section{RESULTS}

The results of the study are described in terms of the demographic profile of the participants, the physical measurements relating to diabetes complication risk factors, information regarding the type 2 diabetes diagnosis, health education received, risk perception and lifestyle modification of the participants.

\section{Demographic profile of the participants}

The demographic profile of the participants will be described in terms of their age, marital status, gender, educational level, employment and socio-cultural group. The participants' ages ranged from 30 to 75 years with the median age group of 41 $50(40 \% ; n=16)$. The majority of members of the sample were married $(77.5 \%)$ and female $(77.5 \%$; $n=31)$. The majority of the group $(75 \%)$ were educated up to a tertiary level. In addition, $85 \%$ of the participants were employed in the educational and commercial sectors. The majority of the participants $(62.5 \%)$ belonged to the Northern Sotho socio-cultural group and 20\% were White.

To provide evidence that the participants were selected according to the inclusion criteria, the length of time that the participant had been diagnosed with type 2 diabetes, as well as the length of time that he/she had been exposed to the education of the Centre for Diabetes were investigated. In terms of duration of type 2 diabetes diagnosis, $40 \%$ of the participants were diagnosed between $1-4$ years, $17.5 \%$ between 5-9 years and the rest (37.5\%) of the group more than 10 years. The majority of the group members $(60 \%)$ had been consulting the Centre for between 1-3 years, and the remainder for an even longer period of time.

TABLE 3

Education and counselling topics attended $(n=40)$

\begin{tabular}{lcc}
\hline TOPIC & $\mathbf{n}$ & $\%$ \\
\hline Medication & 9 & 22.5 \\
Exercise & 17 & 42.5 \\
Symptoms of diabetes & 3 & 7.5 \\
Diet & 23 & 57.5 \\
Eye care & 5 & 12.5 \\
Foot care & 8 & 20 \\
Weight control & 1 & 2.5 \\
Family support & 1 & 2.5 \\
\hline
\end{tabular}

TABLE 4

Importance of regular health care contact $(n=40)$

\begin{tabular}{|c|c|c|c|c|}
\hline \multirow{2}{*}{$\begin{array}{l}\text { HEALTH } \\
\text { PROFESSIONAL }\end{array}$} & \multirow{2}{*}{$\begin{array}{c}\text { IMPORTANT } \\
\text { TO CONSULT } \\
\text { YES } \\
\% \\
\end{array}$} & \multicolumn{3}{|c|}{ LEVEL OF IMPORTANCE } \\
\hline & & $\begin{array}{c}\text { None } \\
\%\end{array}$ & $\begin{array}{c}\text { Intermediate } \\
\%\end{array}$ & $\begin{array}{c}\text { Very } \\
\%\end{array}$ \\
\hline Eye specialist & 97.5 & 0 & 10.3 & 89.7 \\
\hline Podiatrist & 95 & 0 & 15.4 & 84.6 \\
\hline Dietician & 90 & 2.6 & 23.1 & 74.4 \\
\hline
\end{tabular}




\section{Physical measurements of the participants}

Five physical measurements indicating possible long-term complications of type 2 diabetes were taken: weight, height, blood pressure, $\mathrm{HbA1c}$ and waist circumference. The results are provided in Table 1.

For the study, obesity was defined as a BMI $\geq 25 \mathrm{~kg} / \mathrm{m}^{2}$ which includes the overweight, obese and severely obese categories. When evaluating the group in terms of this definition, $85 \%$ were above normal weight (Table 1). Using the value of $\geq 140 / 90 \mathrm{mmHg}$, or taking anti-hypertensive medication (WHO 1999) as the cut-off point for hypertension, $35 \%$ of the sample were hypertensive. In terms of the $\mathrm{HbA} 1 \mathrm{c}, 65 \%$ of the study sample was above the accepted cut-off point and 70\% had a waist circumference above the cut-off point (Table 1).

Investigating the results in relation to the demographic variables, no clear trend could be established. One exception, however, was the physical measurements of the younger group (41-50 years). All (100\%) were obese, $31.3 \%$ were hypertensive, $50 \%$ demonstrated above normal $\mathrm{HbA} 1 \mathrm{c}$ and $68.8 \%$ had a waist circumference above the cut-off point. No clear trend could be found in terms of education or the employment status of the socio-cultural group. The majority of the participants $(80 \%)$ received only oral medication for type 2 diabetes control. Only five participants $(7.7 \%)$ received both injectable insulin and an oral treatment.

\section{Perception of control of type 2 diabetes}

One dichotomous question: Do you consider your diabetes to be well controlled at the moment? was asked to interrogate participants' perceptions of the control of their condition. Almost nine of every 10 of the participants $(87.5 \%)$ indicated that their condition was well controlled. The participants' knowledge of what exactly was implied by control was also investigated. Only half of the group $(52.5 \%)$ indicated that control implied that their blood glucose level would be in the required range when tested. The rest did not know what diabetic control means.

To provide further evidence of the influence of perception of control, the sample was divided into a well controlled and poorly controlled group based on the participants' perception of whether their type 2 diabetes was controlled or not. A comparison of the two groups and their physical measurements and perceptions of seriousness of their type 2 diabetes is provided in Table 2.

From Table 2, no significant association exists between the dichotomous question of whether the type 2 diagnosis was serious and their perception of control. However, a significant association $(p<0.05)$ was found between the physical measurements and the visual analogue scale regarding the seriousness of the type 2 diabetes diagnosis.

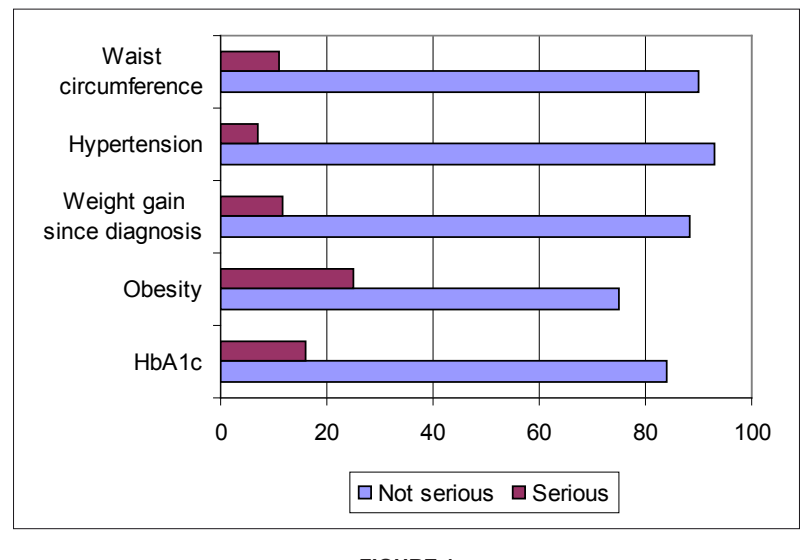

FIGURE 1

Participants with abnormal physical measurements and their perception of seriousness of the type 2 diabetes diagnosis (\%)

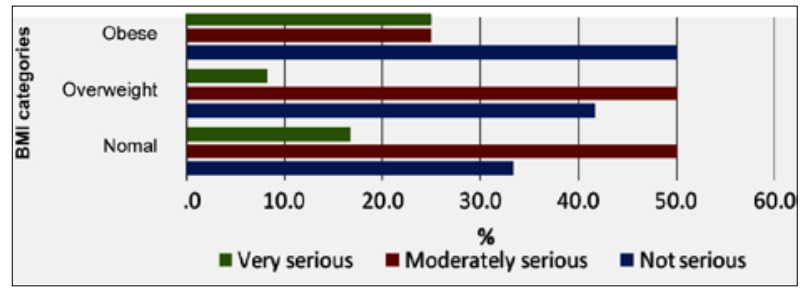

FIGURE 2

Participants' perception of seriousness of type 2 diabetes diagnosis per BMI category $\left(x^{2}=18.2, \mathrm{p}=0.0\right)$

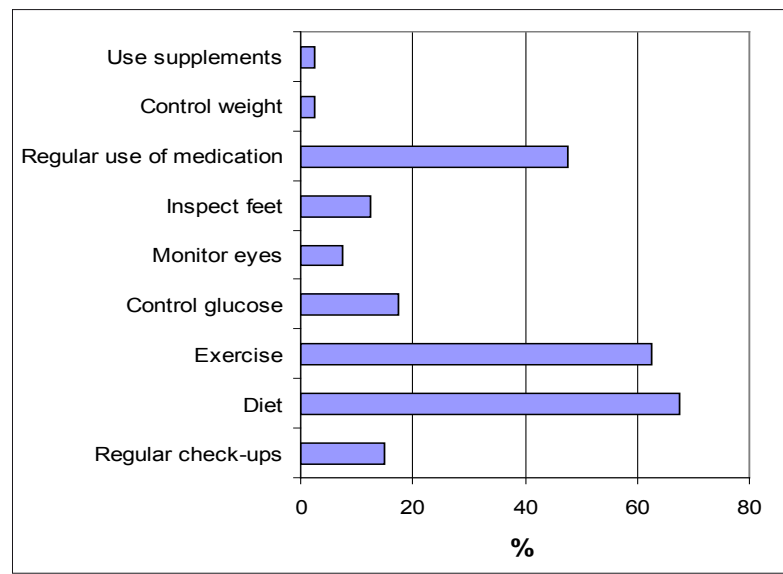

FIGURE 3

Methods listed to prevent complications of type 2 diabetes $(n=40)$

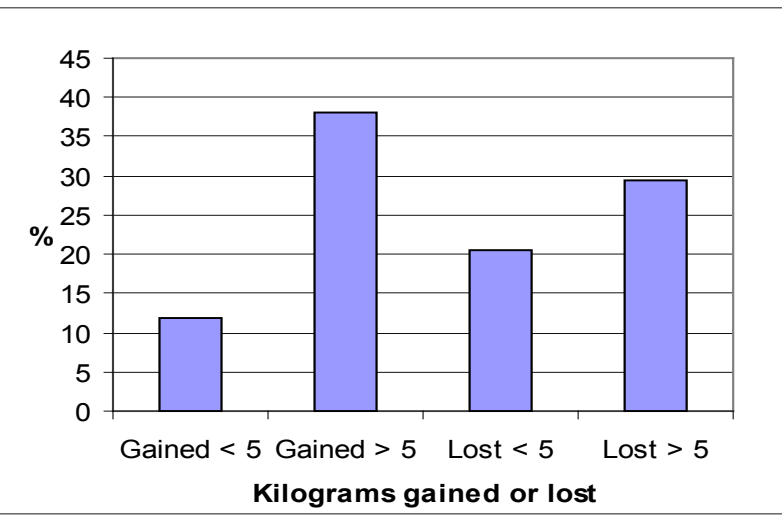

FIGURE 4

Participants' change in weight since type 2 diabetes diagnosis $(n=35)$

\section{Health education and counselling received, and adherence to health-promoting actions}

The number of education and counselling sessions attended was investigated. Half of the group (50\%) attended at least three sessions, $20 \%$ between four to seven sessions and the rest of the group attended more than seven sessions. The topics attended and the percentage of participants who attended are provided in Table 3.

The most popular topics that participants attended were change of diet $(57 \%)$ and the importance of exercise $(42.5 \%)$. When asked if they actually followed the advice they received from the Centre, $92.5 \%$ of the participants responded in the affirmative (yes). The participants were also given an opportunity to indicate which of the pieces of advice they found easy or difficult to follow at home. The advice most easily followed was on dieting $(57.5 \%)$, exercise $(47.5 \%)$ and adherence to the medication regimen (15\%). Other participants though, reported that they found advice regarding diet $(35 \%)$ and exercise $(12.5 \%)$ difficult to follow. A 
few individuals also mentioned foot care, not consuming alcohol and not smoking.

\section{Seriousness of type 2 diabetes diagnosis}

Several questions were asked to investigate the perception of risk involved for the participant in terms of their type 2 diabetes diagnosis. The first question was: 'When you heard your diagnosis of type 2 diabetes, did you think you were seriously ill?' Four out of every ten (42.5\%) participants indicated that they did not perceive the diagnosis as serious when they were first diagnosed. In response to another question: 'On a scale of one to ten, how serious do you think your diabetes is now?' it was revealed that only $12.5 \%$ of the participants perceived their type 2 diabetes as serious at that moment $(0=$ not serious and $10=$ very serious). The perception of seriousness of the type 2 diabetes diagnosis of the group with abnormal physical measurements is illustrated in Figure 1.

A significant association was found between the perception of seriousness and the physical measurements: (waist circumference $(p=0.006)$, hypertension $(p=0.05), H b A 1 c(p=0.03)$ and BMI categories $(\mathrm{p}=0.00)$. Figure 2 provides more detail on the relationship between the participants' perception of seriousness and their BMI category. Of concern is that half of the participants in the obese group did not consider their type 2 diabetes as serious (Figure 2). To explore situational factors that could influence the participants' perception of the seriousness of their condition, a question was asked on whether the participants knew someone else with a type 2 diabetes diagnosis. The majority (92.5\%) indicated that they did know someone and more than half of those known (54.5\%) were considered to be in good health

The participants' perceptions regarding the complications of type 2 diabetes that should be considered as serious revealed that eye complications (52.5\%) were considered most serious. Other complications mentioned were cardiovascular disease $(37.5 \%)$, foot problems $(27.5 \%)$, kidney problems $(17.5 \%)$ and infections $(15 \%)$. The majority $(85 \%)$ of the participants felt capable of preventing these complications. Interestingly, $87.8 \%$ of the group who thought they were to be able to prevent the complications did not consider their type 2 diabetes serious at that moment.

Methods indicated to prevent the complications are presented in Figure 3.

Diet $(67.5 \%)$ and exercise $(62.5 \%)$ were the most frequent methods envisaged to prevent the complications of type 2 diabetes (Figure 3).

Due to the importance of lifestyle changes in the management of type 2 diabetes, changes made in terms of diet, exercise, smoking, and alcohol use were investigated. Diet changes were investigated in several ways. To provide physical evidence that a change in diet had indeed occurred, the participants' weight when diagnosed was compared to their current weight. The results are illustrated in Figure 4.

As is clear from Figure 4, half of the participants (50\%) actually gained weight since their diagnosis. Three in ten of the participants (38.2\%) gained more than five kilograms (range 5-30 $\mathrm{kg}$ ) between their diabetes diagnosis and participation in the study. Changes in diet that participants reported to have made were to reduce fat content $(32.5 \%)$, the intake of sugar $(30 \%)$ and the intake of carbohydrates (12.5\%), to increase the intake of vegetables $(12.5 \%)$, and to stop consuming alcohol $(10 \%)$. The participants were also asked if they were of the opinion that losing weight would lower their blood sugar and $82.5 \%$ replied positively.

In terms of exercise, all the participants knew that exercise would lower their blood sugar. $80 \%$ also indicated that they exercised three times a week. The group who did not participate in any physical activities blamed work-related issues, physical disability, tiredness and laziness as reasons for not exercising. Only four participants $(10 \%)$ were currently active smokers. In an investigation of the complications of smoking for people with diabetes, only $12.5 \%(n=5)$ listed blood circulation and heartrelated health problems as potential complications. A larger number of participants were using alcohol (47.5\%), ranging from one to five units per day. Only ten participants mentioned that the use of alcohol would raise a person's blood sugar.

Two final questions to investigate the importance of lifestyle change on being diagnosed with type 2 diabetes were asked. The first question: 'Has it been possible to change your lifestyle since you were diagnosed with type 2 diabetes?' resulted in $81.6 \%$ positive answers. In the second question, a visual analogue scale was used to address the importance of lifestyle change. The larger majority $(84.2 \%)$ of the participants indicated that lifestyle change is very important. To determine whether changes in their lifestyle had actually been implemented, participants' physical measurements were cross-tabulated with the perceived possibility to change their lifestyle categories. The evidence again suggests that though seven to eight of every 10 participants indicated that it was possible to change their lifestyle, the physical measurements were still abnormal.

Regular health care contact forms part of the management programme of a diabetic person. Table 4 indicates the reported importance of consulting an eye specialist, podiatrist and dietician regularly.

As is clear from Table 4, almost all participants considered it important to regularly visit an eye specialist, podiatrist or dietician important. Though $90 \%$ of the participants indicated that visiting a dietician was important, only $74.4 \%$ thought it was very important. Linking this result to the methods of preventing complications (Figure 3), only $15 \%$ of the group listed regular check-ups as a method of preventing complications.

\section{DISCUSSION}

Based on the results and the theoretical basis of the study, several important points emerged.

\section{Individual perceptions}

Just more than half $(57.5 \%)$ of the participants did not perceive the diagnosis of type 2 diabetes as serious when first diagnosed and $87.5 \%$ did not do so when asked during the study. The lack of seriousness is supported by the results of the study. Supporting evidence is the lack of interest in gaining knowledge about type 2 diabetes; just more than half of the group attended a talk on diet. Only one person attended a talk on weight control. In addition, 57.7\% reported that they found it easy to follow the prescribed diet at home, though only $15 \%$ of the participants' weight was normal and only $35 \%$ had a normal waistline. Another finding was the fact that half the group gained weight since their diagnosis.

According to the Health Belief Model (Pender et al. 2002:37), lack of perceived severity induces a person not to feel vulnerable. In type 2 diabetes management, maintaining a normal blood sugar level equates to being well controlled. More supporting evidence that the participants did not perceive their diagnosis as serious is their perception that their type 2 diabetes was well controlled. Almost all $(87.5 \%)$ the participants perceived their type 2 diabetes to be well controlled, although $65 \%$ of the sample's $\mathrm{HbA1c}$ was above the cut-off point. The lack of preventive action (low attendance of educational talks, low knowledge of how to prevent complications, above normal physical measurements) is also indicative of the lack of perception of seriousness of the diagnoses.

Perceived barriers were investigated but no evidence could be found. When asked if they could implement the preventive 
measures at home, $81.6 \%$ indicated that they could change their lifestyle due to their type 2 diabetes diagnosis.

\section{Modifying factors}

In terms of the demographic variables, the $41-50$ age group was associated with more risk factors and less preventive actions. The participants had a higher socio-economic level in terms of education and employment. A body of literature (Lindau et al. 2002; Pignone et al. 2005; Powell, Hill \& Clancy 2007; Weiss 2007) supports the association between low literacy, poverty and low health literacy. Based on the literature, it could be expected that the participants would adhere to health-promoting actions but the results of the study do not support the assumption.

Another modifying factor, knowing other persons with type 2 diabetes, also did not assist in increasing the participants' perception of seriousness as almost all of the participants knew someone but considered them to be in good health. Though the influence is only indirect, it diminishes the relationship with the perception of the threat. Keogh et al. (2007) provide support regarding the influence of a person's perception of threat. They used the Self-Regulatory Model of Illness Behaviour (Leventhal et al. 2003:42-65), which proposes that in response to a health threat, people form their own common sense beliefs or illness perceptions about their illness and treatment. These perceptions about their illness influence the health behaviours the patients use to manage their disease. This in turn may affect disease outcomes. In addition, it was found that patients with poor diabetes control hold different perceptions of their disease in comparison to those in good control (Leventhal et al. 2003:4265).

Figure 4 illustrates that the only modifying factor that had a positive impact on behavioural change was whether the participant's home situation enabled these persons to change their lifestyles. The group who responded positively with regard to the influence of their home environment on their condition had a lower proportion of abnormal physical measurements in comparison with any other perception indicator. Keogh et al. (2007) confirm the importance of family members in effective diabetes care.

\section{Likelihood of action}

The basic premise of the Health Belief Model (Pender et al. 2002:36) is that the perceived seriousness of the disease is basic to all further decisions taken. Due to the participants' lack of perceived seriousness, the likelihood of taking the recommended action, as is supported by the results, is low. If a person perceives that his or her type 2 diabetes is not serious and that it is well controlled, there is no motivation to take further preventive action. Farmer et al. (2008:20) report the importance of understanding the psychological underpinning of patients' behaviour and using psychological theory and evidence to reduce the gap between intention and behaviour.

\section{LIMITATIONS OF THE STUDY}

The results are not generalisable to a larger context due to the convenient nature of the sample. In addition, the convenient sample precludes any statistical analysis or hypothesis testing. Only one Centre for Diabetes in one province was used to gather data for the study.

\section{RECOMMENDATIONS}

The study raises several questions and the following topics for research are suggested:

- Evaluation should be undertaken of the content of the education and counselling sessions to determine how the seriousness of type 2 diabetes is conveyed to clients.

- $\quad$ The development of the complications of type 2 diabetes is a long-term process. Research should investigate the perceptions of seriousness of a disease with slowly developing complications compared to a disease with sudden complications, for example a myocardial infarction. How to educate persons with type 2 diabetes on the relationship between slowly developing complications and the seriousness of the disease must be investigated.

- Research should be done to investigate whether the participants' physical measurements would improve if education and counselling was individually structured within the context of their home situation.

\section{CONCLUSION}

The chronicity of chronic diseases poses a serious challenge to health promoters. If patients feel well, can go to work and enjoy their leisure time, their perceptions are such that they believe their disease is well controlled and that they are not seriously ill. Health professionals must take cognisance of the patients' perceptions and the context in which proposed interventions will be implemented. Interventions which do not take the psychological foundations of patient behaviour into account will not succeed. The reality is that the psychological underpinning of people varies across socio-cultural groups. Therefore, research to understand these perceptions must precede any intervention. Solutions for how to educate a person to change his/her lifestyle to prevent the complications of type 2 diabetes when he/she is feeling well have not yet been found.

\section{REFERENCES}

Brink, H.I., 2001, Fundamentals of research methodology for health care professionals, Struik, Cape Town.

Caballero, E., 2007, Ethnicity, metabolism and vascular function: The basics for clinical practice, viewed 29 June 2007, from http:// www.medscape.com/viewarticle/557238.

Casellini, C. \& Vinik, A., 2007, 'Clinical manifestations and current treatment options for diabetic neuropathies', Endocrine Practice 13(5), 550-566.

Clark, M., 2004, Understanding diabetes, Wiley \& Sons, London.

Denscombe, M. 2007. The good research guide for small-scale social research projects, 3rd edn., OpenUniversity Press, Berkshire.

Distiller, L., 2006, Diabetes care for health professionals: Diagnosis, classification $\mathcal{E}$ pathophysiology of diabetes mellitus, Centre for Diabetes and Endocrinology, Johannesburg.

Huang, E., Brown, S., Ewigman, B., Foley, E. \& Meltzer, D., 2007, 'Patient perceptions of Quality of Life with diabetesrelated complications and treatments', Diabetes Care 30(10), 2478-2483.

Farmer, A.J., Prevost, A.T., Hardeman, W., Craven, A., Suton, S., Griffen, S.J. \& Kinmonth, A., 2008, 'The support and advice medical trial group', BMC Family Practice 9, 20.

Hurd, R.H., 2007, HbA1c, viewed 07 January 2008, from http:// www.nlm.nih.gov/medlineplus/ency/article/003640.htm.

Keogh, K.M., White, P., Smith, S.M., McGilloway, S., O’Dowd, T. \& Gibney, T., 2007, 'Changing illness perceptions in patients with poorly controlled type 2 diabetes: A randomised controlled trial of a family-based intervention: Protocol and pilot study', BMC Family Practice 8, 36.

Leventhal, H., Brissette, I., \& Leventhal, E.A., 2003, 'The selfregulation of health and illness behaviour', in L. Cameron \& H. Leventhal (eds.), The self-regulation of illness behaviour, Routledge, New York.

Lindau, S.T., Tomori, C., Lyons, T., Lizbet, L., Bennett, C.L. \& Garcia, P., 2002, 'The association of health literacy with cervical cancer prevention knowledge and health behaviours in a multiethnic cohort of women', American Journal of Obstetrics and Gynecology 186, 938-943.

Lo Biondo-Wood, G. \& Haber, J., 2006, Nursing research: Methods and critical appraisal for evidence-based practice, 6th edn., Mosby, St Louis.

Pender, N.J., Murdaugh, C.L. \& Parsons, M.A., 2002, Health promotion in nursing practice, 4th edn., Prentice Hall, New Jersey. 
Pignone, M., Dewalt, D.A., Sheridan, S., Berkman, N. \& Lohr, K.N., 2005, 'Interventions to improve health outcomes for patients with low literacy: A systematic review', Journal of General Internal Medicine 20(2), 185-192.

Polit, D.F. \& Hungler, B.P., 1997, Essentials of nursing research: Methods, appraisal, and utilization, 4th edn., Lippincott, Philadelphia.

Powell, C.K., Hill, E.G. \& Clancy, D.E., 2007, 'The relationship between health literacy and diabetes knowledge and readiness to take health actions', Diabetes Education 33(1), $144-151$.

South African Department of Health, 2002, South Africa demographic and health survey 1998, viewed 16 March 2005, from http://www.doh.gov.za/facts/1998/sadhs98/.
Tan, M.Y., 2004, The relationship of health beliefs and complication prevention behaviours of Chinese individuals with type 2 diabetes mellitus, viewed 20 May 2006, from http://www. sciencedirect.com/science.

Van der Merwe, M.T., 2004, 'The importance and predictive value of BMI and waist circumference in the development of type 2 diabetes', South African Family Practice 46(6), 10-14.

Visser, A. \& Snoek, F., 2004, 'Perspectives on education and counseling for diabetes patients', Patient Education and Counseling 53, 251-255.

Weiss, B.D., 2007, Health literacy and patient safety: Help patients understand, viewed 16 July 2009, from healthlitclinicians. pdf.

World Health Organization, 1999, Guidelines for the management of hypertension, WHO, Geneva. 